https://doi.org/10.17048/AM.2020.311

\title{
Huszthy Viola
}

Eszterházy Károly Egyetem, Neveléstudományi Doktori Iskola

violahuszthy@gmail.com

\section{Az autonóm tanuláshoz szükséges tanári és tanulói kompetenciák di- gitális tanulási környezetben}

\section{Absztrakt}

Doktori tanulmányaim során az idegennyelv-tudás önálló fejlesztésének lehetőségeit kutatom az aktuális digitális pedagógiai környezetben. Másodéves doktorandusz hallgatóként a kutatás megalapozó fázisánál tartok, vagyis célom a későbbi empirikus kutatás stabil elméleti bázisának kialakítása. Elméleti, strukturáló munkám során dokumentumelemzés révén szeretném az autonóm, tanuláshoz szükséges tanári-, valamint tanulói kompetenciákat minél pontosabban meghatározni, definiálni a mai elektronikus tanulási környezetben.

A digitális technológia alkalmazása ma már a modern pedagógia megkerülhetetlen része, a felsőoktatásban egyre inkább elterjednek a távoktatási formák, míg a középiskolákban a digitális tanrend kihívásaival kellett/kell megküzdenie a tanulóknak, tanároknak. Ezekből is kitűnik, hogy az önszabályozott tanulásra való képesség fontossága napjainkra jelentősen megnőtt, a továbbtanulás sikerességének egyik kulcsa.

Az elméleti kutatás során tehát az autonóm tanulás négy fő területéhez kapcsolódó kompetenciákat azonosítom tanári és tanulói oldalról, ezek a kogníció, motiváció, viselkedés és kontextus. Az előkutatás eredményei amellett, hogy a későbbi empirikus kutatás alapjául szolgálnak, segítséget nyújthatnak a tanulóknak autonómiájuk hatékony fejlesztésében, a tanároknak pedig támogatás lehet, a paradigmaváltás korában az esetleges attitűdbéli változáshoz.

Kulcsszavak: autonóm tanulás, önszabályozott tanulás, digitális tanulási környezet, autonóm tanulás kompetenciái, szerep, motiváció, kontextus, kogníció, digitális kompetencia

\section{Bevezető}

Az utóbbi időkben egyre nagyobb szerepet kap az autonóm tanulás, az autonóm tanuláshoz szükséges kompetenciák fejlesztése az oktatásban. Jelen tanulmány tervezett doktori kutatásom beveze- 
tő, elméleti-megalapozó részeként is szolgál, amelynek célja a későbbi empirikus kutatás stabil elméleti bázisának kialakítása. A tervezett kutatás munkacíme: Az idegennyelv-tudás önálló fejlesztésének lehetőségei digitális tanulási környezetben. Ennek megelőző részeként, az autonóm tanuláshoz szükséges kompetenciák előbb általánosságban kerülnek górcső alá, amelyek a későbbiekben az idegennyelv-tanulásra adaptálhatók.

A jelenlegi elméleti, strukturáló munkában az autonóm tanuláshoz szükséges tanári-, valamint tanulói kompetenciák körvonalazódnak dokumentumelemzés révén, a kompetenciák meghatározása mellett pedig az ezekhez kapcsolódó problémakörök is felvetődnek.

Az elméleti kutatás során azonosított négy fő terület a kogníció, a motiváció, a viselkedés és a környezet. Az előkutatás eredményei, amellett, hogy a későbbi empirikus kutatás alapjául szolgálnak, segítséget nyújthatnak a tanulóknak autonómiájuk hatékony fejlesztésében, a tanároknak pedig támogatás lehet, a paradigmaváltás korában az esetleges szemléletváltáshoz.

Az alábbiakban, szakirodalmi szintézis alapján egy olyan kompetencia-térkép rajzolódik ki, amely segítséget nyújthat az autonóm tanulás megvalósításában.

\section{Az autonóm tanulás jelentősége napjainkban}

A 21. századi pedagógiai kutatások egyik központi témája az autonóm, önszabályozott tanulás (Self-regulated Learning), amely kulcsfogalom, a tanulási motiváció kutatásainak területéből kelt önálló életre (Réthy, 2002). A téma megjelenése a pedagógiai kutatásokban a 70-es, 80-as évekre tehető, majd az iránta való érdeklődés erőteljesen nőtt a 90-es években, az elmúlt év fordulópontja következtében pedig az autonóm tanulás relevanciája tagadhatatlanná vált, számos kutatás foglalkozik a területtel. A 2020-ban kényszerből bevezetett digitális tanrend nyomán világossá vált, hogy korunk egyik legfontosabb kompetenciaterülete a hatékony, önálló tanulás kompetenciájának és önszabályozó készségek megfelelő kialakítása (NAT 2020), vagyis a tanulói autonómia maximális fejlesztése.

A tanulói autonómia kialakításához, fejlesztéséhez a pedagógus aktív és határozott közremúködésére van szükség. Az önszabályozott tanulás egyik nagy paradoxonja, hogy a tanuló önállóságát maga a tanár kezdeményezi, ahogy azt a téma egyik korai kutatója Henri Holec megfogalmazta. Tanár és tanuló közös együttmúködéséből születhet valódi autonómia a tanulás folyamatában (Holec, 1981).

A 21. században a tartalmi tudás egyre inkább a készségbeli, a kompetenciabeli tudásra, a know how-ra helyeződik át, a mit tud helyett sokkal inkább fontosabbá válik a mire képes, hogyan tudja elérni jellegű tudás (Z. Karvalics, 1997). Korunk oktatásának problémáira és kihívásaira, az autonóm tanulási kompetenciák fejlesztése lehet az egyik válasz. 


\section{Az autonóm tanulás definíciói és négy fő területe}

Az autonóm tanulás főbb területeit illetően többféle felosztás található a szakirodalomban, amelyek a téma korai kutatása óta folyamatos mozgásban, fejlődésben vannak. Ugyanakkor ezeket öszszevetve a legfontosabb területek négy pontban szintetizálhatók, ezek a kogníció, a motiváció, a viselkedés és a környezet.

Csíkos Csaba (2007) megfogalmazásában az önszabályozó tanulás egy komplex, interaktív, az akarat által vezérelt folyamat, amelyben szerepet játszanak a motiváció, és a kognitív önszabályozó tevékenységek is.

A Tseng, Dörnyei és Schmitt (2006) által végzett kutatásban az önszabályozott tanulás 5 területét azonosították: az elkötelezettség szabályozását, a metakognitív szabályozást, az unalom leküzdésének szabályozását, az érzelemszabályozást és a környezet szabályozását.

Zimmerman és Schunk (2008) leírásában az önszabályozás egy olyan folyamat, amelynek során a tanulók megtanulják szabályozni gondolataikat, érzelmeiket, viselkedésüket, valamint környezetüket.

Az autonóm tanulás kutatásának jelentős magyarországi szakértője D. Molnár Éva a következőképpen gondolkodik a témáról: az önszabályozó tanulással kapcsolatos kutatások arra keresik a választ, hogyan tudják a diákok saját tanulási folyamatukat irányítani, erőfeszítéseiket fenntartani annak érdekében, hogy rövid és hosszú távú céljaikat elérjék. A legtöbb elméleti modellben az önszabályozott tanulás, mint komplex folyamatok szisztematikus rendszere jelenik meg, amelynek egyaránt részei kognitív, affektív, motivációs és környezeti tényezők. $(2013,2009)$.

Jelen tanulmányban a fent említett szakirodalmak alapján, valamint Pintrich (2000), Zimmermann (2000) és D. Molnár Éva (2013) elméleti modelljeit felhasználva kerülnek meghatározásra az autonóm tanuláshoz szükséges tanári és tanulói kompetenciák főbb területei, ezek az alábbi táblázatban láthatók összefoglaló jelleggel, és a 4.-es pont alfejezeteiben kerülnek részletes kifejtésre.

1. táblázat az autonóm tanuláshoz szükséges tanári és tanulói kompetenciák föbb területei

\begin{tabular}{|c|c|c|}
\hline & Tanár fö kompetenciái & Tanuló fö kompetenciái \\
\hline Szerep, viselkedés & Szerepváltozás & Felelősségvállalás \\
\hline Kontextus, környezet & $\begin{array}{c}\text { Digitális kompetencia } \\
\text { Környezet újraértékelése }\end{array}$ & $\begin{array}{c}\text { Digitális kompetencia Személyes } \\
\text { tanulási környezet }\end{array}$ \\
\hline Kogníció & "A proaktív tanár” & "Az autonóm tanuló” \\
\hline Motiváció, érzelem & Bizalom, elfogadás & $\begin{array}{c}\text { Érzelmi tudatosság } \\
\text { Az önismeretre kész én }\end{array}$ \\
\hline
\end{tabular}




\section{A négy fő területhez rendelhető tanári és tanulói kompetenciák}

Az alábbiakban ezen négy terület tanári (T-kompetencia) és tanulói kompetenciáinak ( $D$ kompetencia = diák komp.) rövid elemzése következik, az adott területekhez tartozó egyéb problémakörök megemlítésével.

\subsection{Szerep, viselkedés}

Az autonóm tanulás megvalósulásához elsősorban szükséges, hogy a tanulás-tanítási folyamat résztvevői átgondolják saját szerepüket, szerepkörüket, valamint az ahhoz kapcsolódó kompetenciákat. E nélkül a nézőpontváltás nélkül az önszabályozott tanulás nehezen valósulhat meg.

\section{D-kompetencia: Felelősségvállalás}

Az autonóm tanulás viselkedésre vonatkozó területén a diák legfőbb kompetenciaterülete a tanulásért való felelősségvállalás. A felelősségvállalás már egy érettebb felfogást feltételez a tanuló részéről, és bár az autonómia kialakítása hosszú folyamat, a diáknak valamilyen szinten fel kell nőnie a feladathoz, hogy autonóm tanuló váljék belőle.

Ahhoz, hogy ez megtörténhessen, tulajdonképpen ki kell lépnie a hagyományos, „alárendelt” diák szerepből. Többé nem az a diák, aki tanári utasításra vár és a számonkérésre reagálva tanul, hanem egy olyan tanuló, aki kézbe veszi saját tanulásának irányítását, képes kijelölni saját céljait, képes megtervezni a tanulás folyamatát, a célok eléréséhez megfelelő stratégiákat (metakognitív stratégiák) alkalmaz, és hajlandó a kitartó erőkifejtésre, vagyis irányítottból, irányítóvá, tudatos tervezővé válik. (Benson, 2001)

Mindezt természetesen nem egyedül, magára hagyva teszi, hanem tanára háttérből történő aktív segítségével, motiválásával, indirekt navigálásával. Bizonyos értelemben a diák saját maga tanárává kell váljon.

\section{T-kompetencia: Szerepváltozás}

Az autonóm tanulást támogató pedagógusi viselkedést leginkább a szerepváltozással írhatjuk le. A napjainkban zajló pedagógiai paradigmaváltás idején, nem újdonság a tanári szerep átalakulásának témája. Az önszabályozott tanulás területén a pedagógus feladataként még markánsabban megjelenik a tudatos szerepátalakításra, illetve az új szerep integrálására való törekvés. A viselkedést illetően ez a fő kompetenciaterület, egyben az egyik fő kihívás is. A tanulói autonómiát támogató tanár immár nem lehet többé az ismeretek egyedüli forrása, és nem lehet a kontroll kizárólagos fenntartója. A pedagógus új szerepbe kerül, egy facilitátor, tutor, válik belőle, aki hajlandó a korábban kizárólag saját körébe tartozó feladatok közül többet is átengedni a diáknak. (Nahalka, 2002) A diákot önálló- 
ságában segítő társként van jelen az oktatás folyamatában. (D. Molnár, 2013). Emellett a tanár maga is, mint élethosszig tanuló diák, saját szerepváltozásával járó új kompetenciák elsajátításával, mintegy mintául is szolgál tanulói számára, mint önfejlesztő, élethosszig tanuló egyén.

\subsection{Kontextus, környezet}

A környezeti hatások erősen befolyásolják az autonóm tanulás kialakulását (Boekaerts, Pintrich és Zeider, 2000). Jelen tanulmányban a környezet kapcsán, inkább a digitális tanulási környezetre irányítom fókuszt. Persze mindeközben sosem felejtkezhetünk meg arról a tényről, hogy a környezetnek meghatározó részét képezik a társas kapcsolatok, hiszen a tanulás folyamata a környezettel (társakkal) való interakciók során megy végbe (Komenczi, 2009).

Azonban a digitális oktatás jelenlétének korában a tanulás kontextusát egyre inkább meghatározza az elektronikus tanulási környezet, amely nagyban szélesíti az autonóm tanulás lehetőségeit is, ezáltal az egyik fő szerepet a digitális kompetencia kialakítása kapja. Komenczi Bertalan 2013-as könyvéből idézve „A digitális tanulási környezet folyamatosan gazdagodó eszköztára azt szolgálja, hogy a tanuló érdeklődésének, kognitív stílusának és tanulási preferenciáinak megfelelően a lehető legmesszebb jusson el ismeretei bővítésében, képességei kifejlesztésében."

\section{D-kompetencia: Digitális és információs kompetencia, személyes tanulási környezet}

Az önszabályozott tanulásnak korunk jellemző környezete a digitális tanulási környezet, amelyben a diáknak óriási információs tömegben kell eligazodnia. Elengedhetetlen tehát, hogy az autonóm tanuló magas szintű digitális- és információs kompetenciával rendelkezzen.

Az információs kompetencia nem csupán az IKT-eszközök használatának képességét jelenti, hanem azt is, hogyan képes a diák az információt elérni, és azt megfelelően felhasználni (Rab, 2007). Tehát az információs kompetencia egyrészt egy eszközhasználathoz kötődő képesség, másrészt információ fellelés- és felhasználás képessége. Az információ azonosításának, felhasználásának és beépítésének pedig lényeges eleme a kritikus gondolkodás.

Ezen kívül az autonóm tanulás megvalósulásának egyik fontos ismertetőjegye a személyre szabottság, fontos, hogy a diák kialakíthassa személyes tanulási terét, vagyis olyan környezetet teremtsen maga körül, ami illeszkedik egyéni igényeihez, erre pedig kiváló lehetősége nyílik az elektronikus tanulási környezetben (Racskó, 2017).

\section{T-kompetencia: Digitális kompetencia, környezet újraértékelése}

A pedagógus számára mindenekelőtt fontos a megváltozott kontextus észlelése és elfogadása. Egyrészt saját szerepváltozásának, másrészt a diákok szerepváltozásának tükrében is újra kell értékelnie a tanulási-oktatási környezetet. Ha a tanulói autonómia fejlesztését szem előtt tartja, töreked- 
nie kell a hatékony tanulási környezetek megteremtésére mind kontakt, mind távórák esetében. Távórák esetében ezt leginkább saját IKT kompetenciájának fejlesztésével, módszertani továbbképzésével teheti meg. A tanárok jó részének ma, mint digitális bevándorlóknak (Prensky, 2001), az elektronikus tanulási környezet megismerése, felfedezése és az ebben való jártasság elsajátítása nagy kihívást jelent. Elengedhetetlen feladat a környezet folyamatos újraértékelése is, az utóbbi időben ezt a digitális oktatás (tanrend) is kikényszeríti, megköveteli. Az autonómiát szem előtt tartó pedagógus újraértékeli, mind a kontakt, mind a távórák környezeteit, ennek fényében tanítási gyakorlatát és mindkét környezetben adekvát módon törekszik a tanulói autonómia fejlesztésére.

\subsection{Kogníció}

A mentális folyamatoknál rajzolódik ki előttünk a nagybetűs Autonóm Tanuló képe, aki magas szintű önkontrollra, és különböző önszabályozó stratégiák alkalmazására képes. Az autonóm tanulás fogalmában erőteljesen megtalálható a konstruktivista tanuláselmélet. Ennek korai gondolata Piaget megfogalmazásában - annyit tesz, hogy a tanuló nem csupán passzívan vesz részt a tanulási folyamatban, hanem a korábbi tudása, előzetes tapasztalatai alapján aktivizálódik. Tehát a tudás egy aktív, belső, kognitív építkezés eredménye, minden diák magában konstruálja meg egyéni világképét, tudását (Nahalka, 2002). Ezen egyéni és önálló tudásalkotásban segítik őket a pedagógusok.

\section{D-kompetencia: „Az autonóm tanuló”}

A kognitív folyamatok szintjén az autonóm tanuló tehát aktívan részt vesz a tanulási folyamatban, a tudás elsajátításának folyamatában különböző kognitív, metakognitív és önszabályozó stratégiákat képes hatékonyan alkalmazni tanulási céljainak elérése érdekében. (Pintrich, 2000). Egy tudatos kognitív tervező és aktivizáló munkát folytat. A konstruktivista tanuláselmélet alapján az előző ismeretek aktivizálása szinte magától megy végbe a tanulási folyamatban, azonban egy autonóm tanuló esetében ez nagyobb mértékű tudatossággal zajlik. Ezen kívül fontos az ún. kognitív monitorozás, vagyis a tanuló képes legyen reflektálni saját tanulási cselekvéseire (metakognitív bírálat), és képes legyen értékelni az alkalmazott stratégiákat (metakognitív tudatosság) (Pintirich, 2000). Az ideális autonóm tanulót tehát magas szintű önismeret és céltudatosság jellemzi, képes a megfelelő metastratégiák megválasztására és a tanulási folyamat szinte teljes körű menedzselésére.

\section{T-kompetencia: „A proaktív tanár”}

Ha a diákot „Az autonóm tanuló” névvel illettük, akkor a pedagógusra „A proaktív tanár” kifejezést aggathatnánk a kogníció területén. Ahogy a bevezetőben is elhangzott Holec (1981) híres kulcsmondata: a tanuló önállóságát a tanár kezdeményezi. Ez lehet a jelmondata a tanulói autonómiát támogató pedagógusnak is, aki proaktív módon elősegítheti diákját különböző metastratégiák megismer- 
tetésével, önismereti gyakorlatokkal, az információs kompetencia fejlesztésével, fejlesztő értékeléssel és számos egyéb lehetőséggel tanári kelléktárból. A lényeg, hogy a tanár megértse, tudatosítsa, a diák autonómiájának növelésével nem tûnnek el korábbi feladatai, csak megváltoznak, egy másik szemszögből tekint innentől a tanítás-tanulás folyamatára. Új szerepköréből pedig tudatosan támogatja diákját az autonóm tanulóvá válás útján.

\subsection{Motiváció, érzelem}

Az autonóm tanulás utolsó, de semmivel nem kevésbé fontos alkotóeleme a motivációs és érzelmi bázis, és ezek szabályozása. Ahogy a tudatosság magas szintjét, úgy az érzelemszabályozás magas szintjén is el kell érnie a tanulónak.

\section{D-kompetencia: Érzelmi tudatosság, az önismeretre kész én}

A tanuló részéről az érzelmi szabályozás az egyik legnagyobb kihívás, hiszen életkortól, önismerettől, élettapasztalattól is függ, mennyire képesek monitorozni és kontrollálni saját affektív apparátusukat. Az érzelmek és motiváció szabályozása magában foglalja a célirányultság, az önhatékonyság és az érdeklődés szabályozását (Molnár, 2013). Az érzelmi tudatosság már a célok kijelölésénél is fontos szerepet kap, az önhatékonyság aktiválásával a diák felméri saját képességeinek meglétét és szintjét egy adott szituációban, az érdeklődés szabályozásánál pedig az érdeklődés aktiválása, fenntartása, és olyan érzelemszabályozó stratégiák kerülnek előtérbe, mint az unalom vagy szorongás leküzdése és különböző érzelmi megküzdési stratégiák alkalmazása (D. Molnár, 2013). Az autonóm tanulás minden területén döntő szerepe van az önismeretnek, de ez talán az érzelmi szabályozásnál a legkirívóbb. A diák nyitott kell legyen saját magára, készen kell álljon a magas szintű önismeretre, ez segítheti leginkább őt a hatékony autonóm tanulásban.

\section{T-kompetencia: Bizalom, elfogadás}

Érzelmi szabályozás tekintetében a pedagógus jóval kedvezőbb pozícióból indul, ugyanakkor a felnőtt tanárnak is nagy kihívást jelent az új szereppel járó nehézségek megoldása, és az új kihívások, szituációk elfogadása, integrálása. A tanár feladata a folyamatban, hogy diákjait ismervén, segítse őket a megfelelő érzelmi és motivációs stratégiák megtalálásában, kiválasztásában. Mint kulcskompetencia, ezt a bizalom és elfogadás szavakban lehet leginkább összefoglalni. A tanár helyezze bizalmát a diák képességeibe, merje elengedni a kezét, merjen több önállóságot hagyni neki, ehhez pedig nagy bizalom szükséges a tanár részéről. Mindezek után pedig, hajlandó legyen elfogadni az autonóm tanulással járó következményeket kontextusbeli és szerepbeli változásokat, képes legyen elfogadni a diákok autonómiáját. 


\section{5. Összegzés}

Bár megtévesztő lehet, hogy jelen tanulmányban az autonóm tanulás négy területe, meglehetősen feldarabolva, szétszálazva, különálló kategóriákként vannak ábrázolva, jellemezve, ugyanakkor ezek a gyakorlatban elválaszthatatlanul összefonódnak, nincs egyik a másik nélkül, s együttműködve hozhatják létre az autonóm tanulást. A főbb kompetencia köröket összegezvén elmondható, hogy a tanár elsődleges feladata a változásra való képesség, a diáké pedig, hogy önmagát mindinkább megismerje. A tanár változásra való képességével egy élethosszig tanuló felnőtt mintáját is adja tanulói számára. A tanárnak némileg a diák kompetencia területeibe kell „belekóstolnia” (pl.: digitális kompetencia, facilitátor, mint diáktárs) a tanulónak pedig a tanáréba (tanári szerepkörök átvétele, felelősségvállalás, irányítás). Ebben a szerepcsere helyzetben a tanulási-tanítási folyamat mindkét résztvevője rendkívül sokat „okulhat”, fejlődhet, profitálhat.

Végezetül ki kell hangsúlyozni, hogy a fent vázolt, egy elméleti, erősen idealizált modell, nem várható el a diákoktól a minden téren magasan funkcionáló tudatosság, szabályozottság. Az autonómia formálása már kisiskolás korban elkezdődik, és egy hosszú folyamat, amely folyamat újabb és újabb lépései során mindig sok függ az előzetes tapasztalatoktól. A középiskolában tehát rendkívül fontos szerepet kap az autonóm tanulási képességek, kompetenciák megfelelő kialakítása, a felsőoktatásban pedig már feltételezhető a diákok magasabb önismereti szintje, ezáltal ebben a közegben az oktatók már bátrabban támaszkodhatnak a tanulók autonómiájára, nem felejtkezve meg annak permanens fejlesztéséről.

\section{Irodalomjegyzék}

Bárdos, J. (2000). Az idegen nyelvek tanításának elméleti alapjai és gyakorlata. Nemzeti Tankönyvkiadó, Budapest.

Benson, P. (2001). Teaching and researching learner autonomy in language learning. Longman, London.

Csíkos Cs. (2007). Metakogníció - A tudásra vonatkozó tudás pedagógiája. Műszaki Kiadó, Budapest.

Csizér, K., és Kormos, J. (2012). A nyelvtanulási autonómia, az önszabályozó stratégiák és a motiváció kapcsolatának vizsgálata. Magyar Pedagógia (1.), 3-17.

D. Molnár, É. (2013). Tudatos fejlődés - Az önszabályozott tanulás elmélete és gyakorlata. Akadémiai Kiadó, Budapest.

D. Molnár Éva (2009). Az önszabályozás értelmezései. Magyar Pedagógia, 109. 4. sz. 343-364.

Holec, H. (1981). Autonomy in Foreign Language Learning. Pergamon, Oxford. 
Komenczi, B. (2013). Elektronikus tanulási környezetek kutatásai. Eszterházy Károly Főiskola nyomdája, Eger.

Nahalka I. (2002). Hogyan alakul ki a tudás a gyerekekben. Konstruktivizmus és pedagógia. Nemzeti Tankönyvkiadó, Budapest.

Nemzeti Alaptanterv 2020. file:///C:/Users/IIC101/Downloads/MK 20 017.pdf (letöltés ideje: 2020.09.27.)

Pintrich M., Zeidner M. (Eds.). (2000): Handbook of self-regulation. Boekaerts, Academic https://doi.org/10.1016/B978-012109890-2/50052-4

Pintrich, P. (2000). The role of goal orientation in self-regulatedlearning. In P. Pintrich , M. Boekaerts, \& M. Zeidner, Handbook of self-regulation. CA Academic, San Diego.

https://doi.org/10.1016/B978-012109890-2/50043-3

Prensky, M. (2001). Digital Natives, Digital Immigrants, Part 1. On the Horizon, NCB University Press 9.5. Press. San Diego. https://doi.org/10.1002/9781444318111.ch1

Rab Árpád (2007). Digitális kultúra: a digitalizált és a digitális platformon létrejövő kultúra. In: Pintér Róbert (szerk.). Az információs társadalom: az elméletöl a politikai gyakorlatig. Tankönyv. 182200. Gondolat, Új Mandátum, Budapest.

Racskó, R. (2017). Digitális átállás az oktatásban. Gondolat Kiadó, Veszprém.

https://doi.org/10.17717/IQKONYV.Racsko.2017

Réthy, E. (2002). A kognitív és motivációs önszabályozást kialakító oktatás. Iskolakultúra(2.),7

Tseng, W. T., Dörnyei, Z., és Schmitt, N. (2006). A new approach to assessing strategic learning: The case of self-regulation in vocabulary acquisition. Applied Linguistics, 27. 78-102.

https://doi.org/10.1093/applin/ami046

Zimmerman, B. J. és Schunk, D. H. (2008). Motivation: An essential dimension of self-regulated learning. In: Schunk, D. H. és Zimmerman, B. J. (szerk.): Motivation and self-regulated learning: Theory, research and applications. Lawrence Erlbaum, New York. 1-30.

Z. Karvalics, L. (1997). Az információs írástudástól az Internetig. Educatio. 6(4), pp. 681-698. 